\title{
Experimental Study on Compressive Strength, Water Retention And Water Absorption of self-curing Concrete With Different Curing Conditions
}

\author{
S.P.Raju. $\mathrm{V}^{1}$, Martha Saikumar $^{2}$, T.Srinivas ${ }^{3 a}$, G.V.D.N. SaiVamsi ${ }^{4}$, A. Vijaya Srinivas Srikar $^{5}$ \\ ${ }^{1}$ Assistant Professor, Department of Civil Engineering, GRIET, Hyderabad, India-500090 \\ ${ }^{3}$ Professor, Department of Civil Engineering, GRIET, Hyderabad, India-500090 \\ 2,4,5, UG Students, Department of Civil Engineering, GRIET, Hyderabad, India-500090
}

\begin{abstract}
Curing of concrete is maintaining satisfactory moisture content in concrete during its early stages in order to develop the desired properties. «However good curing is not always practical in many cases, therefore the need to develop self-curing agents attracted several researchers ». "The concept of several self-curing agents is to reduce water evaporation from concrete and hence increase the water retention capacity of concrete compared to conventional concrete, the use of self-curing agent is very important from the point view that water resources are getting valuable every day ». This project summarizes various aspects of self-curing of concrete which can be of valuable assistance in adopting good construction practices at site. M25 grade concrete cube specimens prepared based on the standards and availability of materials without and with $30 \%$ of flyash and quarry dust replaced as cement and fine aggregate and cubes cured by covering them with a external self-curing compound BONDIT CURE WB, air dried and normal water. These specimens are then tested after 7,14 and 28 days to obtain the compressive strength in three different conditions. The compressive strength of concrete cubes is calculated and compressive strength of self-curing concrete is compared with the different conditions. At the end of curing period of 7,14 and 28 days the amount of water retained in self cured concrete cubes is calculated and compared with the air dried cubes. Water absorption test is conducted on air dried concrete and self cured concrete cubes and the amount of water is absorbed is calculate and compared.
\end{abstract}

Key Words : self-curing Concrete, Workability, Water Absorption, Water Retention and Curing Conditions

\footnotetext{
${ }^{a}$ Corresponding Author Email: srinu.tummala@gmail.com
} 


\section{Introduction}

"The concept of self-curing is to reduce the water evaporation from concrete and hence increase the water retention capacity of the concrete compared to conventional concrete, efficient curing improves the strength and durability of concrete, concrete curing compounds is considered to be most important since curing of concrete is a major challenge in the construction industry". "Enough water needs to be present in a concrete mix for the hydration of cement to take place, when the concrete is exposed, water evaporates from its surface, The factors those influences the evaporation are atmospheric temperature, wind velocity, relative humidity, type of cement, initial temperature of the concrete and more importantly free w/c ratio of the mix".

- Experimental Investigations

- Slump Test on Fresh Concrete

- Compressive Strength

"The object of the test is to find out the workability of freshly mixed cement concrete, the slump test is a means of assessing the consistency of fresh concrete, it is used, indirectly, as a means of checking that the correct amount of water has been added to the mix".

Table 1: Properties of Materials

\begin{tabular}{|c|c|c|c|c|}
\hline S.No & Material & proerty & values & $\begin{array}{l}\text { Specified } \\
\text { limits as } \\
\text { per IS } \\
\text { code }\end{array}$ \\
\hline \multirow[t]{5}{*}{1} & \multirow[t]{5}{*}{ Cement } & Fineness & $5 \%$ & $\leq 10 \%$ \\
\hline & & Consistency & $33 \%$ & $\geq 30 \mathrm{~min}$ \\
\hline & & $\begin{array}{l}\text { Specific } \\
\text { gravity }\end{array}$ & 3.15 & $\begin{array}{l}2.90 \text { to } \\
3.15\end{array}$ \\
\hline & & $\begin{array}{l}\text { Initial } \\
\text { setting time }\end{array}$ & $30 \mathrm{~min}$ & $\geq 30 \mathrm{~min}$ \\
\hline & & $\begin{array}{l}\text { Final } \\
\text { setting time }\end{array}$ & $600 \mathrm{~min}$ & $\leq 600 \mathrm{~min}$ \\
\hline 2 & Fly ash & $\begin{array}{l}\text { Specific } \\
\text { gravity-2.2 }\end{array}$ & 2.2 & 2.1 to 3.0 \\
\hline \multirow[t]{2}{*}{3} & \multirow{2}{*}{$\begin{array}{l}\text { Fine } \\
\text { aggregate } \\
\text { (Natural } \\
\text { sand and } \\
\text { Crusher } \\
\text { sand) }\end{array}$} & $\begin{array}{l}\text { Specific } \\
\text { Gravity }\end{array}$ & 2.55 & 2.5 to 2.8 \\
\hline & & $\begin{array}{l}\text { Fineness } \\
\text { modulus }\end{array}$ & 2.46 & 2.4 to 2.8 \\
\hline \multirow[t]{2}{*}{4} & \multirow[t]{2}{*}{$\begin{array}{l}\text { Coarse } \\
\text { aggregate }\end{array}$} & $\begin{array}{l}\text { Specific } \\
\text { Gravity- } \\
2.65\end{array}$ & 2.65 & 2.5 to 3.0 \\
\hline & & $\begin{array}{l}\text { Fineness } \\
\text { modulus }\end{array}$ & 6.1 & 5.5 to 8.0 \\
\hline
\end{tabular}

«The cube specimens were tested on compression testing machine of capacity $2000 \mathrm{KN}$, the bearing surface of machine was wiped off clean and sand or other material removed from the surface of the specimen, the specimen was placed in machine in such a manner that the load was applied to opposite sides of the cubes as casted that is, not top and bottom ». The axis of the specimen was carefully aligned at the centre of loading frame. «The load applied was increased continuously at a constant rate until the resistance of the specimen to the increasing load breaks down and no longer can be sustained, the maximum load applied on specimen was recorded, the compressive strength of concrete cubes were determined after 7, 14 and 28days $»$.

Compressive strength $=$ ultimate load $/$ bearing area .

\subsection{Water Retention}

The specimens were prepared and initial weights of all cubes taken. After completion of every curing stage again weights of al lcubes taken and noted it as final weights. The amount of water retained in air dried cubes and self cured cubes is calculated and compared.

\subsection{Water Absorption}

The specimens were prepared and initial weights of all cubes taken. After completion of 7,14 and 28 days of curing period concrete cubes are immersed in water for 24 hours. The amount water absorbed by the concrete cubes are calculated by its initial weight. The amount of water absorption in air dried cubes and self cured cubes is calculated and compared.

Table2: Mix Proprtions

\begin{tabular}{|c|c|c|c|c|}
\hline $\begin{array}{l}\text { Concret } \\
\text { e design } \\
\text { strength } \\
\text { (MPa) }\end{array}$ & $\begin{array}{c}\text { Ceme } \\
\text { nt }\end{array}$ & $\begin{array}{c}\text { Fine } \\
\text { aggrega } \\
\text { te } \\
(30 \% \text { of } \\
\text { quarry } \\
\text { dust) }\end{array}$ & $\begin{array}{c}\text { Coarse } \\
\text { aggregate } \\
(10 \mathrm{~mm}+20 \mathrm{~m} \\
\mathrm{m})\end{array}$ & $\begin{array}{l}\text { w/c } \\
\text { rati } \\
\text { o }\end{array}$ \\
\hline $\begin{array}{l}\text { 25(witho } \\
\text { ut flyash) }\end{array}$ & 425.73 & $\begin{array}{c}(191+44 \\
5)\end{array}$ & $563+563$ & 0.45 \\
\hline $\begin{array}{l}\text { 25(with } \\
\text { flyash) }\end{array}$ & $\begin{array}{c}298+ \\
128\end{array}$ & $\begin{array}{c}(187+43 \\
6)\end{array}$ & $551+551$ & 0.45 \\
\hline
\end{tabular}

\subsection{Slump retention test of concrete}

From the obtained results for conventional concrete slump value is more than the designed slump and for non conventional concrete slump is more than the conventional concrete. As $30 \%$ of fly ash replaced as cement in concrete, it has finer and rounded particles so it consumes lesser water then workability increases. 
Table 3.Slump test retention values

\begin{tabular}{|c|c|c|c|}
\hline s.no & $\begin{array}{c}\text { Design } \\
\text { compressive } \\
\text { strength(MP } \\
\mathbf{a})\end{array}$ & $\begin{array}{c}\text { Dosage of mineral } \\
\text { admixture(percenta } \\
\text { ge) }\end{array}$ & $\begin{array}{c}\text { Slum } \\
\mathbf{p} \\
(\mathbf{m m})\end{array}$ \\
\hline 1 & 25 & 0 & 78 \\
\hline 2 & 25 & 30 & 86 \\
\hline
\end{tabular}

From the obtained results for conventional concrete slump value is more than the designed slump and for non conventional concrete slump is more than the conventional concrete. As $30 \%$ of flyash replaced as cement in concrete, it has finer and rounded particles so it consumes lesser water then workability increases.

\section{COMPRESSIVE STRENGTH}

"The specimens were prepared after completion of required curing period, the specimens were tested for compressive strength, they were tested in a Compression Testing Machine, the rate of loading was maintained as per the requirements given in the code of practice (IS: 516-1969), three specimens of 150mm cubes were tested for required age and the average value of compressive strength was calculated. The results of compressive strength test were tabulated in table".

Table 4. compressive strength results for M25 Grade of concrete

\begin{tabular}{|c|c|c|c|c|c|c|}
\hline \multicolumn{7}{|c|}{ Compressive strength of concrete in $\mathrm{N} / \mathrm{mm}^{2}$} \\
\hline $\begin{array}{l}\mathrm{Cu} \\
\text { rin } \\
\mathrm{g}\end{array}$ & \multicolumn{2}{|c|}{ Air dry } & \multicolumn{2}{|c|}{$\begin{array}{l}\text { Water } \\
\text { curing }\end{array}$} & \multicolumn{2}{|c|}{ self-curing } \\
\hline & $\begin{array}{c}\text { ce } \\
\text { me } \\
\text { nt }\end{array}$ & $\begin{array}{c}\text { Cemen } \\
\text { t+flyas } \\
\text { h }\end{array}$ & $\begin{array}{c}\text { ce } \\
\text { me } \\
\text { nt }\end{array}$ & $\begin{array}{c}\text { Cemen } \\
\text { t+flyas } \\
\mathbf{h}\end{array}$ & $\begin{array}{c}\mathrm{Ce} \\
\text { me } \\
\text { nt }\end{array}$ & $\begin{array}{c}\text { Cemen } \\
\text { t+flyas } \\
\text { h }\end{array}$ \\
\hline 7 & $\begin{array}{l}16 . \\
59\end{array}$ & 17.18 & $\begin{array}{r}23 . \\
25\end{array}$ & 23.65 & 24 & 24.59 \\
\hline 14 & $\begin{array}{l}22 . \\
96\end{array}$ & 23.55 & $\begin{array}{l}29 . \\
63\end{array}$ & 31.40 & $\begin{array}{l}31 . \\
35\end{array}$ & 32.29 \\
\hline 28 & $\begin{array}{r}27 . \\
10\end{array}$ & 28.01 & $\begin{array}{l}31 . \\
55\end{array}$ & 32.88 & $\begin{array}{c}36 . \\
78\end{array}$ & 38.67 \\
\hline
\end{tabular}

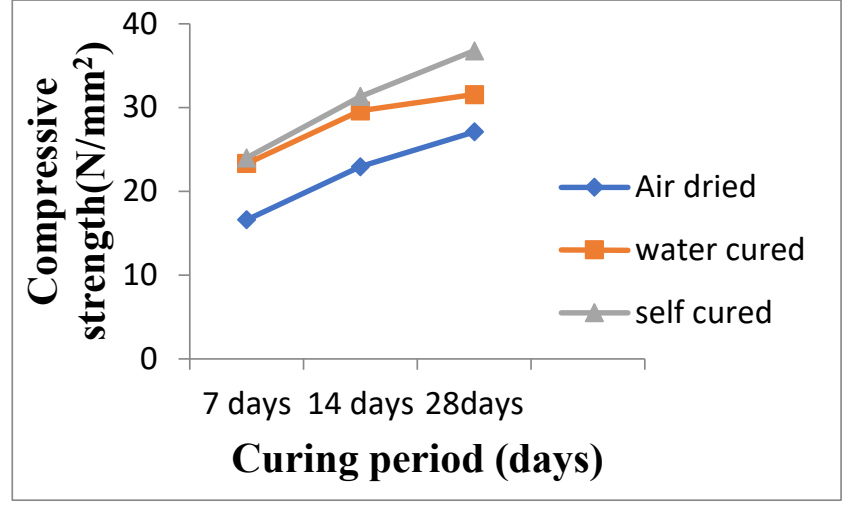

Fig.1.Plot of Curing Period v/s Compressive Strength $\left(\mathrm{N} / \mathrm{mm}^{2}\right)$ without replacement

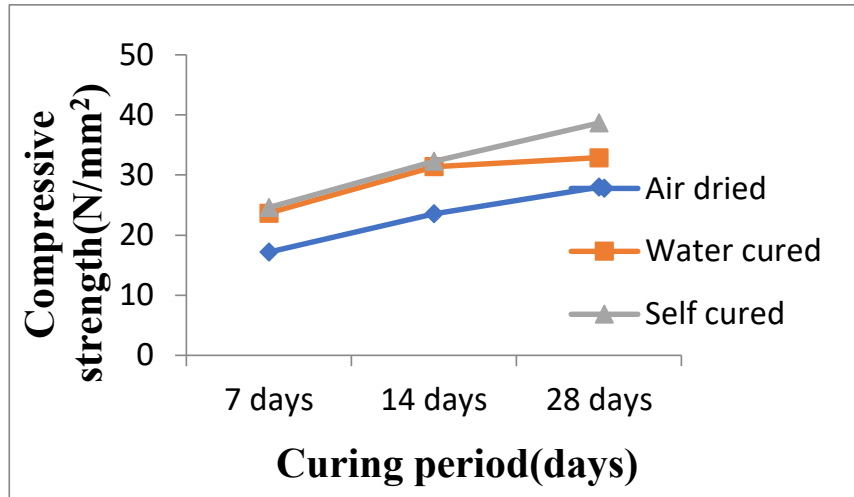

Fig.2. Plot Of Curing Period v/s Compressive strength $\left(\mathrm{N} / \mathrm{mm}^{2}\right) 30 \%$ Partial replacement of flyash

From the results it is observed that compressive Strength of air dried concrete cubes are lesser than compressive strength of water cured, self cured concrete cubes and after completion of 28 days curing period is also lesser than the designed target strength. Because of lack of curing, the amount of water present in the cubes evaporated. So the compressive strength of air dried cubes is less. It shows the curing of concrete is necessary.

The compressive strength of water cured concrete cubes is lesser than the compressive strength of the self cured concrete cubes and more than the strength of the air dried cubes. And it gained designed target strength of after 28 days of curing period. After 7 days curing period it gains $66 \%$ of designed target strength, After 14 days curing period it gains $91 \%$ of designed target strength and After 28days curing period it gains $99 \%$ of designed target strength.

The compressive strength of self cured concrete cubes is higher than all and it gained more than the designed target strength after 28 days of curing period.

After completion of 7 days curing period the compressive strength of self cured concrete is $3 \%$ and 
$3.9 \%$ is more than the water cured concrete cubes without and with replacement.

After completion of 14 days curing period the compressive strength of self cured concrete is $5.8 \%$ and $6.4 \%$ is more than the water cured concrete cubes without and with replacement.

28 days curing period the compressive strength of self cured concrete is $16.5 \%$ and $17.5 \%$ is more than the water cured concrete cubes without and with replacement. Because application self-curing agent on concrete cubes it arrests the water loss from the concrete and the amount of water present in the concrete is efficiently utilized for the complete hydration process. So it is used for getting strength more than the designed target strength.

From the obtained results also observed that compressive strength of non conventional concrete is higher than the compressive strength of conventional concrete at every stage of curing period and air dried, water cured and self cured concrete. Initially after preparation of air dried concrete cubes taken the weights

\section{WATER RETENTION}

The specimens were prepared and initial weights of all cubes taken. After completion of every curing stage again weights of all cubes taken and noted it as final weights. The amount of water retained in air dried cubes and self cured cubes is calculated and compared.

Table 5. Water retention results $\left(\mathrm{M}_{25}\right.$ Grade concrete)

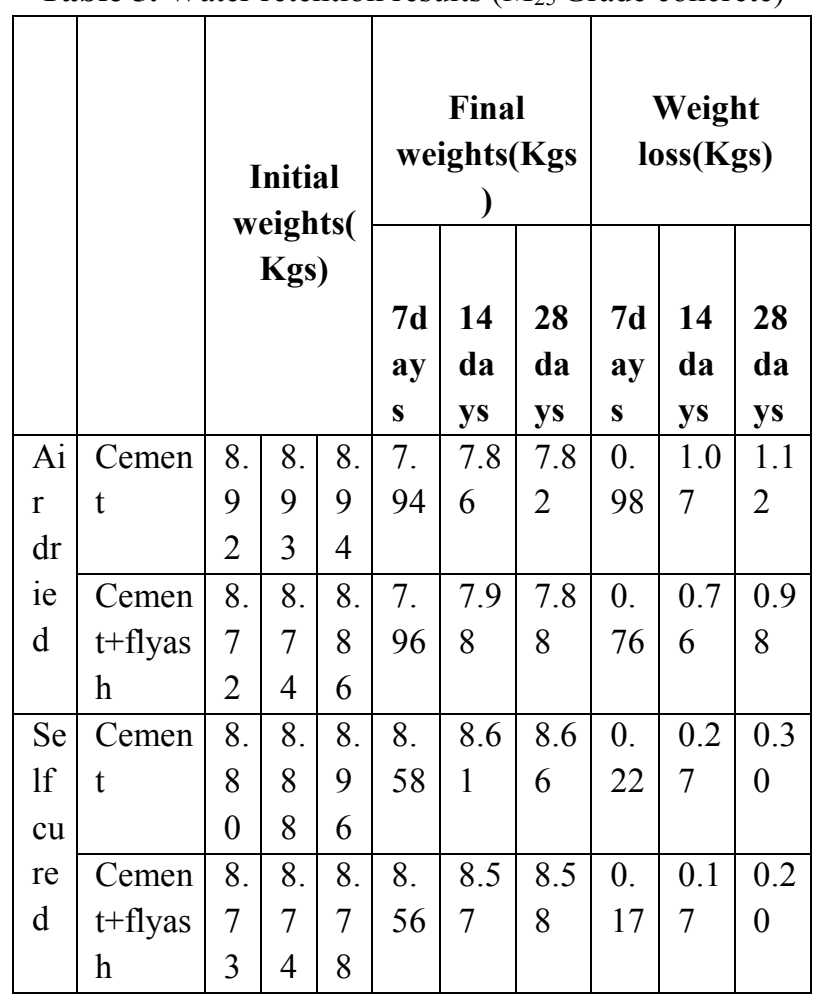

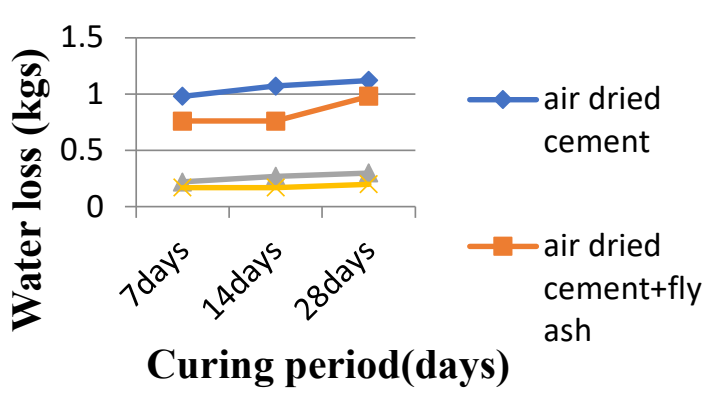

Fig.3.Plot of Curing period v/s water retention

From the obtained results observed that the weight loss of the air dried concrete cubes is more than the self cured concrete cubes. Because of lack of curing the amount of water present in the air dried cubes evaporated. The external application of self-curing agent acts as a barrier to prevents the loss of water from the cubes.

\section{WATER ABSORPTION}

The specimens were prepared and initial weights of all cubes taken. After completion of every curing stage again weights of all cubes taken and noted it as final weights. The amount of water rabsorption in air dried cubes and self cured cubes is calculated and compared.

Table 6. water absorption results ( $\mathrm{M}_{25}$ Grade concrete)

\begin{tabular}{|c|c|c|c|c|c|c|c|c|}
\hline \multirow{3}{*}{$\begin{array}{l}d \\
\mathbf{a} \\
\mathbf{y} \\
\mathbf{s}\end{array}$} & \multicolumn{4}{|c|}{ Air Dried } & \multicolumn{4}{|c|}{ Self Cured } \\
\hline & \multicolumn{2}{|c|}{ Cement } & \multicolumn{2}{|c|}{$\begin{array}{c}\text { Cement+ } \\
\text { Fly Ash }\end{array}$} & \multicolumn{2}{|c|}{ Cement } & \multicolumn{2}{|c|}{$\begin{array}{c}\text { Cement+F } \\
\text { ly Ash }\end{array}$} \\
\hline & $\begin{array}{l}\text { Init } \\
\text { ial } \\
\text { wei } \\
\text { ght }\end{array}$ & $\begin{array}{c}\text { Fin } \\
\text { al } \\
\text { wei } \\
\text { ght }\end{array}$ & $\begin{array}{c}\text { Init } \\
\text { ial } \\
\text { wei } \\
\text { ght }\end{array}$ & $\begin{array}{c}\text { Fin } \\
\text { al } \\
\text { wei } \\
\text { ght }\end{array}$ & $\begin{array}{c}\text { Init } \\
\text { ial } \\
\text { wei } \\
\text { ght }\end{array}$ & $\begin{array}{c}\text { Fin } \\
\text { al } \\
\text { wei } \\
\text { ght }\end{array}$ & $\begin{array}{c}\text { Init } \\
\text { ial } \\
\text { wei } \\
\text { ght }\end{array}$ & $\begin{array}{c}\text { Fin } \\
\text { al } \\
\text { wei } \\
\text { ght }\end{array}$ \\
\hline 7 & $\begin{array}{c}8.9 \\
2\end{array}$ & $\begin{array}{l}9.1 \\
6\end{array}$ & $\begin{array}{c}8.7 \\
2\end{array}$ & $\begin{array}{l}9.0 \\
0\end{array}$ & 8.80 & 8.90 & 8.73 & 8.84 \\
\hline $\begin{array}{l}1 \\
4\end{array}$ & $\begin{array}{c}8.9 \\
3\end{array}$ & $\begin{array}{l}9.3 \\
3\end{array}$ & $\begin{array}{c}8.7 \\
4\end{array}$ & $\begin{array}{l}9.1 \\
8\end{array}$ & 8.88 & 9.02 & 8.74 & 8.89 \\
\hline $\begin{array}{l}2 \\
8\end{array}$ & $\begin{array}{c}8.9 \\
4\end{array}$ & $\begin{array}{l}9.4 \\
5\end{array}$ & $\begin{array}{c}8.8 \\
6\end{array}$ & $\begin{array}{l}9.3 \\
0\end{array}$ & 8.96 & 9.14 & 8.78 & 8.97 \\
\hline
\end{tabular}




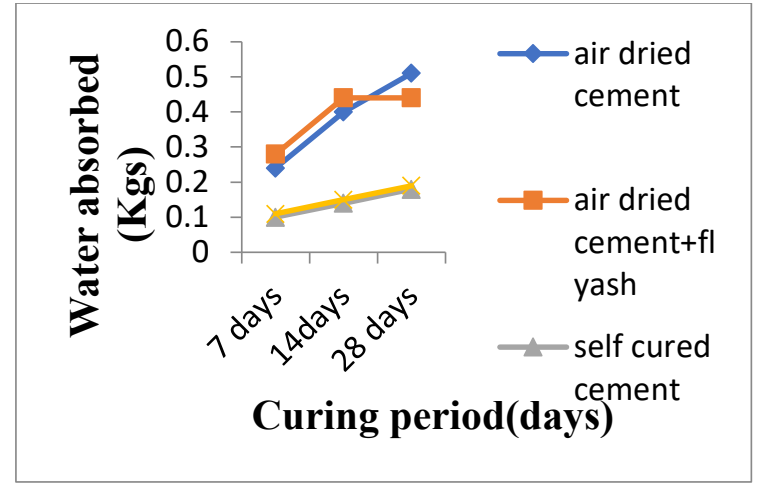

Fig.4.Plot of Curing period vs water absorbed

From the obtained results we observed that water absorbtion of air dried concrete increases with increase in curing period. And water absorption is more in the case of air dried concrete. In self-curing concrete the water absorption is less because external application of self-curing agent. Itforms a thin layer and prevents the entry of water into the concrete.

\section{CONCLUSIONS}

1. Compressive strength of self-curing concrete after 28 days curing period is more than the compressive strength of water cured concrete by $16.5 \%$ and $17.5 \%$ without and with replacement flyash and quarry dust respectively. Because of external self-curing compound complete hydration takes place in concrete and it gives more strength.

2. Compressive strength of air dried concrete cubes is lesser than the designed target strength because lack of curing.

3. The amount water retained in self cured concrete is more than the air dried concrete. Beacause the external self-curing compound forms a thin layer and it arrests the evaporation of water from the concrete.

4. Water absorption capacity of air dried concrete increases with age of curing and it is more than the water absorption in self-curing concrete.

\section{ACKNOLEDGEMENT}

The authors profusely thank Dr.V.Srinivas reddy, Professor, GRIET, Hyderabad for his valuable suggestion and constant support during the progress of this project work.

\section{References}

1. Ahmad Mustafa Sabaoon, Navinderdeep singh(2018) "A Review Paper on self-curing Concrete" International Research Journal of
Engineering and Technology (IRJET), e-ISSN: 2395-0056 Volume: 05 Issue: 01 | Page 745.

2. Amal Viswam, Arjun Murali(2018) "REVIEW ON THE STUDY OF SELF-CURING CONCRETE" Vol-4,Issue-1, IJARIIE-ISSN

3. A. Ananthi, R. Ranjith, S. Swarna Latha, R. Vimal Raj(2017) "Experimental Study on the Properties of Self-Curing Concrete" International Journal of Concrete TechnologyVol.3, Issue1.

4. K V S Gopala krishna sastry,Putturu manoj kumar(2017) "Self-curing concrete with different self-curing agents" ICRAMMCE 2IOP Publishing.

5. Mohammed Shafeeque, Sanofar,Praveen.K, Jithin Raj,Nikhil,Gopikrishna(2017) "Strength Comparison of Self-Curing Concrete and Normal Curing Concrete".International Journal of Advance Research and Innovation IJARI.

6. R.Udhayan,Dr.,N.P.Rajamane(2017)“EXPERIM ENTAL STUDY OF SELF COMPACTING SELF-CURING CONCRETE'International Journal of Civil Engineering and Technology (IJCIET) Volume 8, Issue 4, pp. 638-643.

7. Magda I. Mousa, Mohamed G. Mahdy, Ahmed H. Abdel-Reheem ,Akram Z. Yehia (2016)"Strength Characteristics of self-curing Concrete With Different self-curing AgentS" International Journal of Innovative Research in Science, Engineering and Technology,Vol. 5, Issue 9.

8. Suresh Kumar Tummala, Dhasharatha G, E3S Web of Conferences 87, 01030 (2019).

9. N.VENKATA REDDY, I.S.ANVESH REDDY(2016) "STUDY ON SELF-CURING CONCRETE USING LIQUID PARAFFIN WAX AS EXTERNAL AGENT" IJERGS, Volume 4, Issue 6,November-December, 2016.

10. Ms. Akanksha Anantrao Patil, Prof. M. R. Vyawahare(2014) "Comparative study on Durability of Self cured SCC and Normally cured SCC" IJSRET, ISSN 2278 - 0882,Volume 3, Issue 8 .

11. Mohanraj, Rajendran, Ramesh, Mahalakshmi, Manoj Prabhakar(2014) “An Experimental Investigation of Eco-Friendly Self-Curing Concrete Incorporated with Polyethylene Glycol mix" IARJSET, Vol.1, Issue2.

12. M. Manoj Kumar 1 and D. Maruthachalam(2013) "Experimental Investigation on Self-curing Concrete" IJASTR, Issue 3 volume2 ISSN 22499954 Page 300.

13. M.V.Jagannadha Kumar, M. Srikanth, K. Jagannadha Rao (2012) "STRENGTH 
CHARACTERISTICS OF SELF-CURING CONCRETE" IJRET, ISSN: 2319-1163 Volume: 01 Issue: 01.

14. T.Srinivas and R. N. Koushik, "Sulphate attack Resistance of Geo-polymer Concrete made with Partial Replacement of Coarse Aggregate by Recycled Coarse Aggregate" IJITEE, Volume-8 Issue-12, pp. 112-117 (2019).
15. Srinivasa Reddy, V., Seshagiri Rao, M.V., Shrihari, S, "Appraisal of processing techniques for recycled aggregates in concrete", IJEAT, 8 (6), pp. 1661-1665, (2019).

16. T.srinivas and P. Manoj Anand, "Permeation Properties of Geopolymer Concrete Made with Partial Replacement of Recycled Coarse Aggregates" IJITEE, Volume-8 Issue-12, pp. 2987-2990 (2019). 